\title{
Effects on milk protein yield of graded levels of lysine infused into the duodenum of dairy cows fed diets with two levels of protein
}

\author{
H Rulquin, L Le Henaff, $R$ Vérité
}

Station de Recherches sur la Vache Laitière, INRA, Saint-Gilles, 35590 L'Hermitage, France

Lysine and methionine seem to be the limiting amino acids for dairy cows eating maize diets (Schwab et al, 1988; Le Henaff et al, 1990). In order to determine lysine requirements, graded levels of lysine $(0,15,30,45 \mathrm{~g} / \mathrm{d})$ were infused into the duodenum of dairy cows. Milk yield and composition responses were tested in two trials with protein allowances of either 90 or $105 \%$ of the requirements (diets with 14 or $16 \% \mathrm{CP}$ in DM).

Eight ruminally and duodenally fistulated Holstein cows were used in midlactation in two $4 \times 4$ latin squares. During each period ( 2 wk) they received a duodenal infusion of one dose of lysine $+11 \mathrm{~g}$ of methionine and enough glutamate to reach $9.7 \mathrm{~g} \mathrm{~N} / \mathrm{d}$. The diet consisted mainly of maize silage, maize gluten meal and grain concentrate in respective ratios of $(54,3.3,36 \% \mathrm{DM})$ for the trial with the low protein allowance and $(54,8,32 \%)$ for the other. Milk potential was increased by daily injections of $30 \mathrm{mg}$ of bovine somatotropin (Lilly, France).

Lysine infusions did not affect milk yield or fat content. In each trial, both protein and casein contents increased, especially at the high protein allowance (up to $3.6 \mathrm{~g} /$ $\mathrm{kg}$ ). The response reached a plateau at a lower dose of lysine (15 vs $30 \mathrm{~g} / \mathrm{d}$ ) with the low rather than with the high protein allowance. This indicates that lysine is limiting with maize diets. However, benefit from a lysine supplement might be rapidly limited at low protein levels.

Acknowledgments - Rhône Poulenc Animal Nutrition for funding this research.

Le Henaff L, Rulquin H, Vérité R (1990) Reprod Nutr Dev suppl 2, 237s

Schwab CG, Bozack CK, Mesbah MMA (1988) J Dairy Sci 71 (suppl 1), 160

Table I. Determination of the lysine requirement of lactating cows given either 90 or $105 \%$ protein allowance (PA) diets.

\begin{tabular}{|c|c|c|c|c|c|c|c|c|c|c|}
\hline & \multicolumn{5}{|c|}{$90 \%$ of $P A$ requirements } & \multicolumn{5}{|c|}{$105 \%$ of PA requirements } \\
\hline & 0 & 15 & 30 & 45 & $S E$ & 0 & 15 & 30 & 45 & $S E$ \\
\hline $\begin{array}{l}\text { Milk yield }(\mathrm{kg} / \mathrm{d}) \\
\text { Milk fat content }(\mathrm{g} / \mathrm{kg}) \\
\text { Milk protein content }(\mathrm{g} / \mathrm{kg}) \\
\text { Casein content }(\mathrm{g} / \mathrm{kg})\end{array}$ & $\begin{array}{l}30.0 \\
46.2 \\
31.8 a \\
24.8 a\end{array}$ & $\begin{array}{l}30.0 \\
45.1 \\
32.7 b \\
25.7 b\end{array}$ & $\begin{array}{l}30.4 \\
45.1 \\
32.7 b \\
25.7 b\end{array}$ & $\begin{array}{l}30.5 \\
44.2 \\
32.7 \mathrm{~b} \\
25.7 \mathrm{~b}\end{array}$ & $\begin{array}{l}0.40 \\
0.59 \\
0.14 \\
0.23\end{array}$ & $\begin{array}{l}33.5 \\
42.5 \\
29.0 a \\
23.0 a\end{array}$ & $\begin{array}{l}33.6 \\
40.8 \\
30.3 b \\
24.1 a\end{array}$ & $\begin{array}{l}35.0 \\
42.0 \\
32.0 c \\
25.5 b\end{array}$ & $\begin{array}{l}33.8 \\
45.5 \\
32.6 c \\
26.2 b\end{array}$ & $\begin{array}{l}0.79 \\
0.94 \\
0.21 \\
0.31\end{array}$ \\
\hline
\end{tabular}

